appears sound in principle; is found in practice an insuperable obstacle. It may here be noticed that the revised statutes of Balliol, to which College the outside world is wont to look as the leader in all reform, ordain that all Fellowships shall be filled up after examination, except only in the case of University Professors, or persons eminently qualified to be college tutors. It does not appear from the Report of the Commission that the Cambridge Colleges have yet taken any steps to appropriate definitely any portion of their endowments to the encouragement of scientific research; but it is a matter of common notoriety that at the October election to Fellowships at Trinity College, a candidate was successful whose chief qualification was that he had already accomplished good original work in embryological investigation; and Cambridge men may therefore boast that this one fact is worth all the schemes of the sister University. Both Oxford and Cambridge, however, will have to do much more than they have yet attempted, or than most of itheir members would appear to have yet conceived, before they can satisfy the public wants and justify the retention of their wealth as it now stands disclosed.

In other respects also we are glad to observe that the objectors to the endowment of research are growing less numerous and less violent, and that the details of a scheme by which this object may be furthered are becoming more acceptable to the general public. The question was brought into prominence by an article in the last number of the Fortnightly Review, and the writer of that article has not been slow to strengthen his positions and answer all opponents in the daily and the weekly press. We must confess that we have been fairly surprised to see with what general acceptance his thoroughooing views have been met, and they merely require the approval of persons eminent in their particular sciences in order that they may carry conviction to all impartial minds. The evening organ of the Conservative party concludes a notice of them with the following judicious sentence, which could not have been written a bare twelvemonth ago:- "The general principle of the need of some sort of endowment for science is generally admitted, and in the main features of the scheme there is much to recommend it to a prudent public." The remaining evening papers, which have all called attention to the scheme, are, if not so laudatory, at least critical rather than hostile; for the time seems to have passed when the matter can be thought deserving of being laughed down with a sncer. We feel bound to refer more particularly to a letter contained in the Spectator of October 24, written by the gentlcman referred to above, and entitled, "A Draft Schcme for Endowing Research." The intention of the letter is to show that it is practicable, by means of a judicious application of precarious salaries, to train up a class of scientific investigators, and that it is a safe investment to give endowments to young men before they have reached eminence in their studies. This point deserves the more attention because it appears to be now widely granted that sinecure posts ought to be provided for men of science who are already famous for their discoveries, and for this latter object the Colleges have at present sufficient power, if only the will also were there. The essence of this draft scheme is to be found in the principle, at once comprehensive and simple, that no candidate is to establish his claim to a permanent endowment until he has previously served an apprenticeship of some ten years, during which period he must furnish continual proofs of his aptitude and diligence, and will receive regular payment by results amounting to a continuous salary if his work is satisfactory. The candidates would be originally selected on the nomination of the professor under whom they have studied, tempered by a moderate examination to exclude manifest incompetence; and during their long period of probation they will be continually liable to rejection, if it be found by the board to which this duty is entrusted that they are not worth the money they are receiving. This plan, no doubt, is well worthy of trial at a central University, where the prolonged course of study under the superintendence of professors naturally lends itself to its adoption, and it could scarcely be perverted to greater wastefulness than at present characterises the Fellowship system at Oxford and Cambridge. It may, however, be plausibly suggested that something less elaborate in system and more closely adapted to the wants of specific studies would be required in the pecuniary encouragement of research which it is the duty of the nation, independently of the Universities, to undertake.

\section{GRESHAM COLLEGE}

$\mathrm{N}$ the previous article we speak of the advancement of of scientific research, and here we wish to refer to an excellent article in Monday's Daily Nerws connected with the advancement of education. The misuse and idleness of the untold wealth of the London City Companies we have frequently referred to ; but until the Daily Ncres unearthed the facts contained in its article, few people were aware of the existence of an institution which is one of the most striking anachronisms of our time, and the uselessness of whose cndowments is provoking, now that the importance of scientific cducation to all classes is beginning to be keenly felt, and when its progress is so much hampered by want of means. The writer in the Daily News deserves the greatest credit for the trouble he must have put himself to in obtaining the facts about the institution known as "Gresham College," and for the uncompromising way in which he has stated the facts of the case. It is indeed a hopeful sign of the recognised importance of sound scientific teaching, when the daily press espouses its cause so heartily.

The Daily News article begins by referring to the admirable system of lectures to working men during the winter at South Kensington in connection with the School of Mines, and which are so popular that many are shut out from want of room in the lecture theatre. Each Professor now gives a course of six lectures in alternate years, an average of twenty-four lectures being thus given in the course of the year, in the plainest English, by Professors of the first rank, for the nominal fee of one penny per lecture. "More thronged, more silent, or more attentive audiences," to quote the Daily Neres article, "than those which attend these lectures to working men it would be impossible to find, even in the halls of the most learned of learned societies." This, combined with the results of some of the examinations in the Science and Art Department, seems to us to prove the readiness and eagerness 
of working men to take advantage of instruction in science when there is some guarantee that such instruction is sound and earnest ; and it is a pity, when this is the case, that any time should be lost in devising some system of scientific and technical education suited for the wants of the whole country. At all events the pabulum provided at Gresham College is a sad mockery of this widespread craving for knowledge. Again, to quote the writer in the Daily New's: "While the West is thus enlightened by modern science, in the East a phantasm bedizened in the worn-out rags and tatters of scholasticism provokes contemptuous laughter. In the large lecture theatre which occupies the greater part of the building at the corner of Gresham and Basinghall streets, to an audience composed of perhaps half a dozen persons, who have drifted in from mere idle curiosity, an English divine will read a lecture on astrono:ay in the Latin tongue, followed an hour later by an Ei,glish lecture but little better attended. This, with similar curious exhibitions during Term time, is the outcome of Sir Thomas Gresham's bequest, and the functions of those who were once resident Professors have dwindled to the delivery of these almost unattended lectures." The writer then goes on to tell the melancholy history of the Gresham Fund, and he tells it so well that we shall give the story nearly in his own words.

"The atrophy of Gresham College is well worthy of notice. By the will of Sir Thomas Gresham, the great merchant of Elizabeth's time, and the Founder of the Royal Exchange, were bequeathed, in moieties to the City and Corporation of London and to the Company of Mercers, under certain conditions, 'the buildings in London called the Royal Exchange, and all pawns and shops, cellars, vaults, messuages and tenements, adjoyning to the said Royal Exchange.' To the foundation of a college, 'myne now dwelling-house in the parish of St. Helens in Bishopsgate and St. Peters the Poor' was devotcd, and the 'Mayor and Commonalty' of the City of London were charged with 'the sustertation, maintenance, and finding' of four persons to read lectures on Divinity, Astronomy, Music, and Geometry in the said dwelling-house-a stately mansion. The Company of Mercers was charged with the maintenance of three Professors to lecture on Law, Physic, and Rhetoric, and on both the City and the Company of Mercers was enjoined the performance of sundry charitable duties towards almsmen, poor prisoners, and the like. Celibacy was pronounced an absolute condition of professorship, and the seven lecturers were to reside in 'myne now dwellinghouse,' and were each to receive fifty pounds yearly-no inconsiderable remuneration in the year of grace 1575 , when good Sir Thomas set his 'seal with the grasshopper' to his last will and testament." For a considerable period after the founder's death Gresham College appears to have remained an important institution. Here, on Nov. 28, 1660 , the foundation of the Royal Society was decided upon by a knot of philosophers who had assembled to listen to a lecture on astronomy by Christopher Wren, at that time a resident Professor in the old Gresham Mansion, where the chair of Geometry was filled by the celebrated Hooke. Escaping the Great Fire of London, Gresham College, still a flourishing institution, served for a whilc as Guildhall and Exchange to what was left of the
City, but within the following forty years fell into that decadence from which it has never since emerged. In I706 a memorial was laid before the Lord Mayor and the Court of Aldermen, setting forth grave causes of complaint against the Professors. A dashing pamphleteer of the period also declared that the Professors, albeit "gentlemen of civility, ingenuity, and candour," yet seemed to discover an "unwillingness and reluctancy to perform their work, because it required some pains and attendance, and were so far from the ambition of being crowded with auditors that they seemed rather to desire to have none at all."

"This state of things was bad enough," continues the writer in the Daily News, "but worse was to follow. In 1768, with the consent of the Grand Committee of the Gresham Trust-which consisted then, as now, of four aldermen and eight commoners of the City of London, and twelve commoners for the Company of Mercers-the Gresham Mansion and the site on which it was built were alienated to the Crown for the purpose of building a new Excise Office. 'Myne dwelling-house' had been scandalously neglected, and allowed to fall into such a dilapidated condition that its unworthy guardians parted with it in consideration of the payment to the City and the Mercers' Company of a perpetual rent of $500 l$. per annum, the City and Company paying $\mathrm{r}, 800 \mathrm{l}$. down towards the cost of pulling down the ancient building and erecting the new office. By this transaction an estate of great value was sacrificed, the handsomest house in London torn down, and the collegiate establishment entirely subverted. A room at the Royal Exchange was set apart for reading the lectures, celibacy was no longer made a condition of professorship, and residence was dispensed with as a matter of course-the lecturers being each allowed 5ol. yearly, in lieu of apartments, over and above the original salary of $50 l$. Owing partly to the incapacity of the Professors and partly to the inconvenient hours at which the lectures were delivered, the attendance of the public diminished, until between the years $x 800$ and 1820 the average number of the audience was only ten at each English lecture and thirteen at all the Latin lectures fo: the whole year. On the burning of the Royal Exchange Gresham College became a nomad institution, the lectures being mumbled or gabbled over in any hole or corner, until I 84 r, when the Gresham Committee purchased the present site, and erected on it a handsome lecture theatre at a cost of $7,000 \mathrm{l}$. On various occasions attempts have been made to modify the constitution of Gresham College; but although it was found possible to entirely overturn the provisions of the 'pious founder' in 1768 , all subsequent interference has been met by the most determinad nposition. It will hardly be credited that a prolonged struggle ensued before the Professors could be brought to issue a syllabus of the lectures to be delivered in each term. Still greater difficulty was experienced in transferring the hours of lecturing to the evening. This innovation was firmly resisted, and it was only by waiting till the tough old irreconcileables were gathered to their fathers that it was at last carried out.

"Very slight improvement has taken place under the new order of things. Shortly before six o'clock on the evenings designated in the syllabus the doors of Gresham College are opened, and a superb beadle looks out to see 
if any human being will be weak enough to enter the hall of dulness. As the clock hands closely approach the hour a thrill of excitement passes through the lecturer and the beadle. Two misguided persons have strayed into the building, and on the arrival of a third depends the reading of the Latin lecture, which is not delivered to a smaller audience than three. Should the third unwelcome guest put in an appearance the deed must be done--the lecturer must make a show of earning the $4 l .3^{s} .4 d$. he gets for reading the Latin discourse. Looking rather flusteredperhaps by the consciousness that three wicked wags have conspired to make him work-he opens a well-dog'scared manuscript, and, reading at a tremendous pace, dashes through a composition which, as a rule, sets criticism at defiance. The good old traditional policy of driving auditors away is well kept up. Long Greek quotations loosely patched together by a rigmarole of doubtful Latinity, and rattled over with an evident intention of getting to the final dixi as quickly as possible, are not calculated to enchain the attention of a modern audience. It is only fair to admit that the lecturer sometimes shows a kecn appreciation of the dreary farce in which he is the chief actor, and on these occasions condescends to address a few words-in English-to such of the audience as may be 'in at the death.' Feeling that a lecture in Latin needs not, therefore, be either tedious, stupid, or confused, he acknowledges the miserable quality of the rubbish he has just rattled through, and excuses it on the ground that the attendance is not sufficiently great to encourage the production of a good lecture; adding, moreover, that if more people came more pains would be taken. This solemn mockery is repeated every term, so that if all the Latin lectures were read, the majority of the professors would each deliver twelve English and twelve Latin discourses for his rool. per annum-by no means an excessive rate of payment if the lectures really instructed anybody in anything. Unfortunately, as at present conducted, Gresham College is utterly and completely useless to any human being save only the professors and the beadles, who draw their salaries with commendable punctuality. Another matter for regret is, that not only is the use of a commodious building lost, but that a collection of books, which if placed in the City Library would be accessible to students, lies buried in the unprofitable seclusion of the College. If the Gresham Committee take no interest in the important trust confided to them, it is indeed high time that public attention was directed to an antiquated and transparent sham, a disgrace alike to the age and to the city in which it is perpetrated,"

We hope that this unsparing exposure will lead to an inquiry into the abuse, and an appropriation of the valuable funds to a purpose much more consistent with the spirit of the will of the benevolent and wellmeaning founder.

\section{HECKEL'S DEVELOPMENT OF MAN}

Anthropogenie oder Entwickelungsgeschichte des Mens:hen; gemeinverständliche wissenschaftliche Vorträge, von Ernst Hæckel. (Leipzig: Engelmann, 1874.)

THE new volume of so-called popular lectures by Prof. I Hæckel bears somewhat the same relation to "The Descent of Man" which his "Schöpfungsgeschichte" did to "The Origin of Species." Few who are acquainted with Mr. Darwin's writings will agree with the criticism lately put forth from the chair of the British Association that they need an expounder. Those, however, who are dissatisfied with his patient analysis of facts and sober deduction of principles will find abundant exposition and extension in such works of his disciples as "The Beginnings of Life," "The History of Creation," and the present volume.

In criticising the vast system of dogmatic cosmogony which is here built up in lectures before a popular audience, one would not for a moment confound it with the flippant confidence of sciolists who attack or defend the theory of evolution, not on its scientific merits, but because it seems to them to support some theological or antitheological prejudice. But it is a matter of deep concern that so justly eminent a biologist as Prof. Hæckel should allow himself, in treating a subject which above all demands the dry light of impartial judgment, to adopt the style of those "who are not of his school-or any school."

The fact is, that the extremely difficult subject of the philogeny of man, demanding an accurate knowledge of embryology and comparative anatomy, both recent and fossil, is not at all fitted for popular treatment. Popularising science ought to mean persuading people to work at some of its branches until they learn to love it, not altering its character so as to make it please the itching ears of idlers.

The really valuable parts of the "Schöpfungsgeschichte" and the "Anthropogenie" must be at once useless and distasteful to such readers; and if they accept all the "advanced" theories laid cut and dried before them, they will be learning a bad lesson in biology. If they happen to have one set of prejudices, they will denounce all science as an invention of the devil; or if they have another, they will degrade it into a mere instrument to insult the feelings of their reighbours. Prof. Hæckel assures his hearers that the history of development contains more valuable knowledge than most sciences and all revelations; but, whether more or less important, the secrets of nature, like those of revelation, can only be gradually learned with patient ear and reverent spirit: they are meaningless or mischievous when accepted without pains or preparation.

Unfortunately, in these lectures the teacher frankly drops the character of the student of nature and assumes that of the combatant. Even in the preface he attacks the "black International" of Rome, "jener unheilbrütender Schaar," with which "at last-at last the spiritual war has begun." We see "the banners unfurled," we hear "the trumpets blown, which muster-the hosts for this gigantic struggle." We are shown "whole ranks of dualistic fallacies falling before the chain-shot of monistic artillery, and libraries of Kirchenweisheit and Afterphilosophie (sic) melting into nothing before the sun of the History of Development." But when these metaphors are dropt, we find that the objects of this gigantic strife are to prevent certain (unspecified) teaching in primary schools, to suppress convents and celibacy by law, to expunge Sundays and saints' days from the calendar, and to forbid religious processions in the streets! 